\title{
Physical quality of seeds of Moquiniastrum polymorphum
}

\author{
J. C. T. Faria ${ }^{*}$, L. A. Melo ${ }^{a}$, C. R. M. Assumpção ${ }^{b}$, G. E. Brondani ${ }^{a}$, T. B. Breier and J. M. R. Faria $^{a}$ \\ aPrograma de Pós-graduação em Engenharia Florestal, Departamento de Ciências Florestais, Universidade Federal de \\ Lavras - UFLA, CP 3037, CEP 37200-000, Lavras, MG, Brasil \\ ${ }^{b}$ Department of Forestry Sciences, University of Helsinki - UH, Viikinkaari 11, 00014, Helsinki, Finland \\ 'Programa de Pós-graduação em Ciências Ambientais e Florestais, Instituto de Florestas, Universidade Federal Rural do \\ Rio de Janeiro - UFRRJ, Rod. BR 465, Km 07, CEP 23897-970, Seropédica, RJ, Brasil \\ *e-mail: jc.tannure@gmail.com
}

Received: February 5, 2017 - Accepted: August 21, 2017 - Distributed: February 2, 2019

(With 2 figures)

\begin{abstract}
This study aimed to analyze the physical properties of the seeds of Moquiniastrum polymorphum when processed by mini-SAS, X-ray and seed blower systems. The seeds were purchased from Seeds Caiçara, located in Penápolis-SP. After purchase, the seed lot was characterized by standard tests. In the X-ray test the seeds were classified according to their internal morphology as filled, unfilled or malformed. The seed blower was set at six opening settings, resulting in light and heavy fractions. The evaluations were performed by weighing the seeds that remained in the blower (heavy fraction) and by the amount of filled seeds indicated by the X-ray test. The germination tests were composed of four replicates of 50 seeds. The mini-SAS was used for external evaluation. It was concluded that the combined use of the seed blower and the X-ray test was efficient for the evaluation and determination of the physical quality of the seeds of M. polymorphum. The seed blower at opening settings 5 resulted in the best lot quality. The external parameters were not able to qualitatively evaluate the seeds of M. polymorphum.
\end{abstract}

Keywords: Gochnatia polymorpha, cambará, X-ray, mini-SAS, seed blower.

\section{Qualidade física de sementes de Moquiniastrum polymorphum}

\section{Resumo}

O presente estudo objetivou analisar as propriedades físicas das sementes de Moquiniastrum polymorphum por meio dos equipamentos raios-X, mini-SAS e soprador de sementes. As sementes foram adquiridas da empresa Sementes Caiçara em matrizes localizadas no município de Penápolis-SP. Após adquirido e beneficiado, o lote de sementes foi caracterizado por meio de testes padrões. No teste de raios-X as sementes foram classificadas de acordo com sua morfologia interna como cheias, vazias ou mal formadas. O soprador de sementes foi ajustado em seis aberturas, resultando em frações leves e pesadas. As avaliações foram realizadas pesando-se as sementes que permaneceram no soprador (fração pesada) e pela quantidade de sementes cheias pela análise de raios-X. Posteriormente foram realizados testes de germinação compostos por quatro repetições de 50 sementes. Na avaliação externa das sementes utilizou-se o equipamento mini-SAS. Após análise dos dados, concluiu-se que a utilização em conjunto dos equipamentos soprador de sementes e raios-X foi eficiente para avaliação e determinação da qualidade física das sementes de $M$. polymorphum. O soprador de sementes na regulagem da abertura 5 resultou na melhor qualidade do lote. Os parâmetros externos não foram capazes de avaliar qualitativamente as sementes de $M$. polymorphum.

Palavras-chave: Gochnatia polymorpha, cambará, raios-X, mini-SAS, soprador de sementes.

\section{Introduction}

The reckless forest exploitation from the past decades, combined with tax incentives for agriculture in addition to the growing interest in timber products have led Brazilian native forests to diminish to a large extent (Rego et al., 2009), even though, according to the Brazilian laws concerning environmental protection (Law 9.605, Art. 50-A - Brasil, 1998, Law 12.651, Art. 31 - Brasil, 2012), deforestation of native forests, without license, is considered a crime. Furthermore, besides contributing to environmental disasters,

such activity might also interfere with the plant/animal interaction that is fundamental to the biological cycle.

The number of native Brazilian forest species with little or no scientific information is still large due to the enormous diversity of species in the ecosystems of the country. However, several studies have been published on the botanical and behavioral character of forest species (Carvalho, 2003; Santos et al., 2011; Souza et al., 2010; Lorenzi, 2014). 
The forest species Moquiniastrum polymorphum (Less.) G. Sancho, formerly known as Gochnatia polymorpha, and popularly known as cambará or candeia, belongs to the family Asteraceae. M. polymorphum can be found in the southern and southeastern regions of Brazil as well as in some areas of the central-western and northeastern regions. Its natural habitat is within the Cerrado biome, Brazilian tropical savanna, in the Ombrophilous Forest and in the Mixed Ombrophilous Forest. Because of its predominance in sites with lack of nutrients, particularly in sandy terrains, it is found in both primary and secondary succession. Even though M. polymorphum appears in several floristic surveys, there are only a few studies about its seed production process (Lorenzi, 2014; Pinto and Kolb, 2015).

The economic value of $M$. polymorphum is mainly attributed to wood that is considered moderately heavy, hard and compact. With the density of $0.76 \mathrm{~g} \mathrm{~cm}^{-3}$, it has high resistance in adverse conditions. The species has also other values, such as pharmacological (leaves with medicinal properties) and landscape (ornamental value). Because its anemochory dispersion, attraction of fauna, fire resistance and regrowth capacity, this is a highly-recommended species for the initial composition of the reforestation in degraded areas (Rossatto and Kolb, 2010; Lorenzi, 2014; Machado et al., 2015).

According to Lorenzi (2014) and Carvalho (2003), $M$. polymorphum produces a large number of seeds, which are contained in the fruits. Even though the seeds do not have dormancy, they lose their germination capacity fast. In fact, their germination is considerably low, between 30 and $50 \%$. Yet, the cause for their low germination index is still poorly reported.

The increasing demand for seeds of native forest species, owing to production and conservation programs of the Brazilian forest sector, has helped develop technologies to enable seed quality evaluation. Among the technologies used in the seed industry, the Seed Analysis System (SAS) is an equipment developed by Tbit used to perform visual analysis of seeds and process the data in graphs, histograms and tables. This tool has become popular as it assists with the distinctions of external characteristics of the seeds (Pinto et al., 2015).

Another common technique in seed analysis is the X-ray test (Carvalho et al., 2009). It originally developed in 1953 in Sweden by Simak and Gustafsson, when testing seeds of Pinus sylvestris L. The X-ray technique has been incorporated in the routine of several seed analysis laboratories, and it provides information on the occurrence of malformed and empty seeds, which may influence the results of germination (Amaral et al., 2011). The X-ray test has been adopted by the International Seed Testing Association (ISTA) when carrying out quality programs and morphological and physiological studies of forest species seeds. The efficiency of this technique has already been proven for the identification of internal characteristics of Tabebuia heptaphylla (Amaral et al., 2011), Cedrella fissilis Vell. (Masetto et al., 2008) and Eremanthus erythropappus (Feitosa et al., 2009) seeds. In all these studies, the X-rays tests showed positive results to seed processing. Furthermore, it labels the empty and damaged seeds, which improves the final lot of germination.

Filled and unfilled seeds also differ in weight and can be separated by processing tests, such as gravity table, centrifugation, separators and solutions (alcohol, maltodextrin, sucrose) (Nogueira, 2007). In addition to these, the seed blower is a seed separator that operates with different opening settings for airflow passage without compromising seed quality. It was efficient in separating empty and full seeds of Eremanthus erythropappus (Feitosa et al., 2009), Agapanthus africanus (Pereira and Carvalho, 2008), Solanum granuloso-leprosum e Solanum pseudoquina (Castellani et al., 2007).

The goal of the techniques that seek to improve the quality of forest seed lots is to select homogeneous material with high physiological potential, thus ensuring the best growth and establishment of the plants in the field. Consequently, there will be greater acceptance in the market and in reforestation activities (Amaral et al., 2011; Nery et al., 2017). This study aimed to analyze the physical properties of the seeds of M. polymorphum when processed by mini-SAS, X-ray and seed blower systems.

\section{Material and Methods}

\subsection{Seed origin and processing}

The experiment was conducted in the Seeds laboratory of the Department of Forest Sciences and in the Seed Analysis laboratory of the Department of Agriculture, both at the Federal University of Lavras, in Lavras, Minas Gerais. The seeds of $M$. polymorphum were purchased from Seeds Caiçara. They were collected in December of 2014 from 20 matrices located in Penápolis-SP, São Paulo, and stored in cold room $\left(5^{\circ} \mathrm{C} / 60 \% \mathrm{RH}\right)$ in semipermeable bags up to the time of purchase.

After acquisition, the seeds were left to dry in the sun for two days for the removal of anemocoric dispersion materials, after which they were shaken and sieved. In this study the dispersion structures known as cypsela were considered seeds (Marzinek et al., 2008). After processed, the seeds were maintained in cold room $\left(5^{\circ} \mathrm{C} / 60 \% \mathrm{RH}\right)$ in semipermeable bags until the beginning of the experiments.

\subsection{Characterization of seed lots}

Standards of purity, moisture, germination, and weight of one thousand seeds were determined according to a seed analysis standard known as "Regras para Análise de Sementes" endorsed by the Ministry of Agriculture (Brasil, 2009).

Because these guidelines do not provide information for the analysis of cypsela dispersal structures, pure seeds were determined according to the definition of achene, once achenes are the closest dispersal elements to cypsela. Thus, all achenes and achene fractions more than half the original size (unless seedless), and seeds and seed fractions more than half the original size, with pericarp and tegument partially or entirely removed were considered 
as pure seeds. Two replicates of 1.0 gram were analyzed and pure seeds were separated from other seeds and inert material. The result was expressed as percentage of pure seeds in the seed lot.

To measure the moisture content, another two 1.0 gram samples were selected. The samples were first placed in aluminum foil, then taken to the oven at $105 \pm 3{ }^{\circ} \mathrm{C}$ for $24 \mathrm{~h}$ and finally cooled with desiccator containing silica gel. The weight of wet samples, dry samples and foil were recorded with an analytical balance of $0.0001 \mathrm{~g}$ accuracy. Moisture content was determined by the average of the replicates calculated through the Equation 1 below:

$\operatorname{MC}(\%)=\frac{w-d}{w-T} \times 100$

where: $\mathrm{MC}=$ moisture content; $\mathrm{w}=$ wet weight; $\mathrm{d}=$ dry weight; and $\mathrm{T}=$ tare.

Four replications of 50 pure seeds were tested for germination. Seeds were washed in sodium hypochlorite at $2 \%$ (two minutes) and rinsed with distilled water. Samples were incubated in a gerbox germinator (with acrylic boxes) at $30{ }^{\circ} \mathrm{C}$ with regular lighting. Blotting paper sheets moistened with distilled water (two and a half the weight of the paper) were used as substratum. The result was expressed as average percentage of normal seedlings. It was considered normal seedlings the ones that displayed uniform and proportional growth of essential structures, such as: aerial meristems; root system, with main root colored white; short and fine secondary roots; main stem colored light green and first pair of leaflets colored dark green.

Eight replications of 100 pure seeds were selected to calculate the weight of one thousand seeds. The calculation was performed according to the seed analysis standard (Brasil, 2009). The seed samples were weighed, averaged and multiplied by ten to obtain the weight of the 1000 seeds. The result was expressed in grams.

\subsection{Quantification, assessment, and separation of unfilled seeds}

Characterization of the physical quality of seeds was performed by a Faxitron X-ray system set at $26 \mathrm{KV}$ and exposure time 16 seconds. The equipment was automatically adjusted based on seed size. The radiography allowed to categorize the seeds in three groups: filled seeds (with well-developed embryo filling the entire interior of the seed), malformed seeds (with the embryo only partially filling the seed), and unfilled seeds (without embryo). Subsequently, each group of seeds was taken to germinate. The seeds were immersed in sodium hypochlorite solution diluted $2 \%$ for two minutes and rinsed in distilled water. The germination test followed the same methodology as in the initial assessment of seeds.

For external evaluation, a mini-SAS was used. The equipment captured high resolution images from the seeds placed in a tray and then had them analyzed with a software. All filled, unfilled and malformed seeds were assessed regarding: dominant color, area, maximum diameter, minimum diameter, maximum/minimum diameter ratio and perimeter.

A DeLeo seed blower (type General) was used to separate embryonic seeds. This equipment regulates the air flow velocity by dividing the original sample into a light and a heavy fraction. A metallic valve numbered from 0 to 25 adjusts the air flow speed, that increases with the number of adjustment. This equipment regulates the air flow velocity by dividing the sample in two fractions, lighter and heavier ones. The equipment is manually adjusted - the greater the calibration, the greater the airflow speed through the equipment. The blower was set at the opening settings $1,2,3,4,5$ and 6 and at 30 seconds' ventilation time. Opening settings were defined in such a way that at least some of the seeds remained in place. Each opening tested corresponded to one treatment with four replicates of two grams of seeds.

After fractions were separated, the heavy fraction was manually purged of residual inert material and seeds were weighed. The weight was converted into percentage of the original weight. The percentage of filled seeds in the heavy fraction was quantified by X-ray analysis, with four replicates of 50 seeds analyzed per heavy fraction. Then, these samples were submitted to germination test, following the same criteria as in the initial assessment of the seed lot. Data were analyzed by SISVAR ${ }^{\circledR} 5.3$ statistical software, comparing means by the Tukey test at a 0.05 level of probability (Ferreira, 2011).

\section{Results and Discussion}

\subsection{Characterization of seed lots}

Original moisture, purity, germination, and weight of one thousand seeds are shown in Table 1. The purity test showed high proportions of impurities, including fragments of leaves and dispersion structure. The lot showed a lower germination rate. Equilibrium moisture content resulted in $8 \%$ and the weight of one thousand seeds was $0.435 \mathrm{~g}$ (Table 1).

Due to the low percentage found in the germination test, the radiograph images were used to characterize the internal properties of the seeds, and the mini-SAS system to evaluate the external properties. The automatic regulation of $26 \mathrm{KV}$ energy settings and exposure time of 16 seconds allowed greater viewing of the internal structures of seeds and distinction of the three seed groups: unfilled seeds (A), malformed seeds (B), and filled seeds (C), as shown in Figure 1.

To distinguish the three groups of seeds, dark image color characterized unfilled seeds due to absence of internal mass, while partially light colored image characterized malformed seeds due to partial presence of internal mass. As for filled seeds, the image was much lighter because of the higher density of tissues, preventing the transposition by x-rays (Figure 1).

Simak et al. (1989) reported that although X-ray testing is not specific to evaluate seed viability, it may reveal embryo formation and morphological damage that 
Table 1. Purity, moisture, germination, and weight of a thousand seeds of seed lots of M. polymorphum.

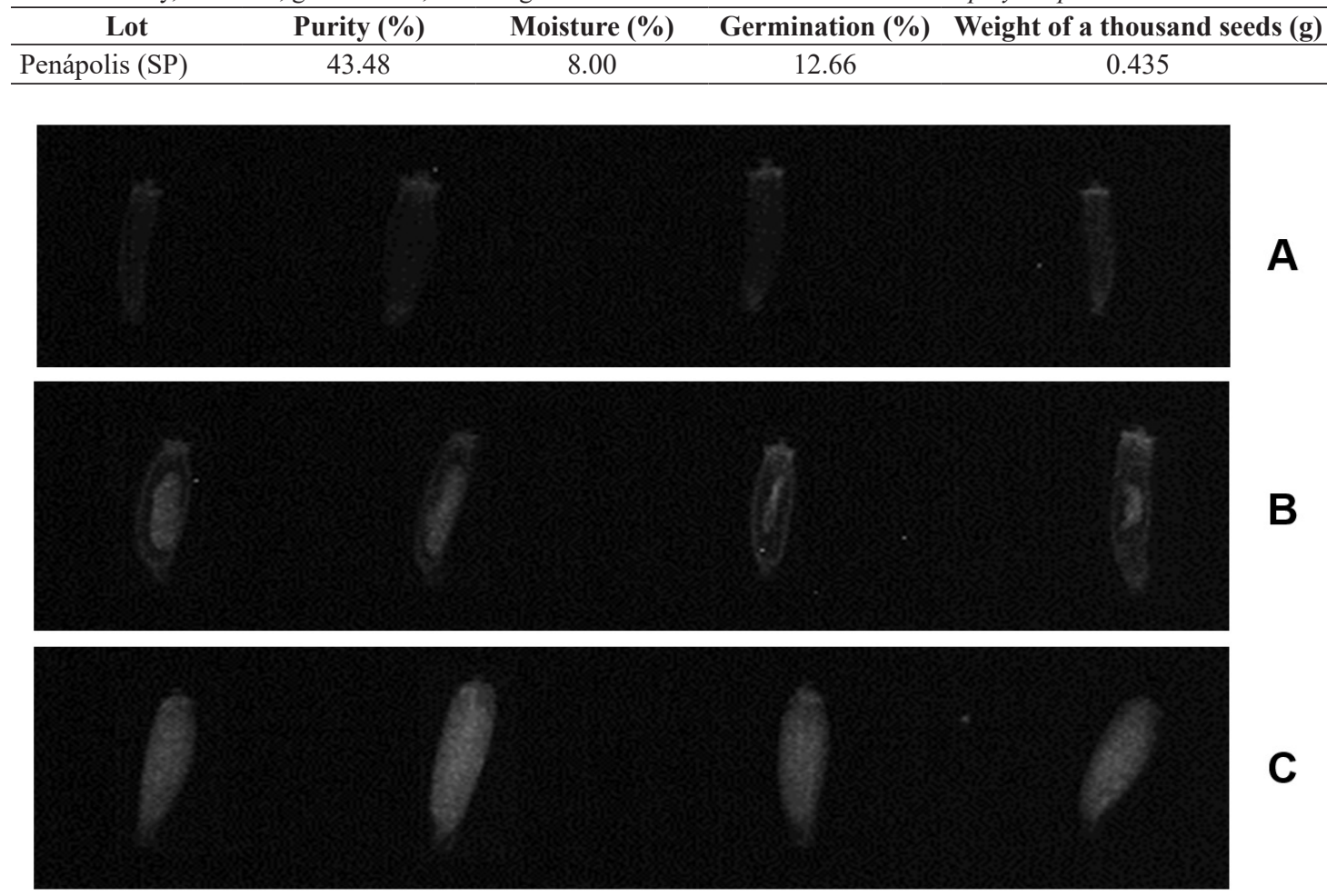

Figure 1. Categorization of M. polymorphum seeds by radiograph images generated by X-ray technique, with the following lines: (A) Unfilled seeds; (B) Malformed seeds; and (C) Filled seeds.

can affect physiological potential. In this experiment, the $\mathrm{X}$-ray technique allowed us to detect several empty seeds, but no insect attack.

The mini-SAS system provided information regarding the size and color of the seeds. All the three groups of seeds were black. The geometric dimensions showed similar mean results for area, maximum and minimum diameter, ratio of maximum and minimum diameter and perimeter (Table 2).

The physiological potential of seeds is inherent to each species. Some studies in the literature argue that the external characteristics of fruits and seeds are important for the understanding of the germination of forest species (Lopes et al., 2005; Silva et al., 2015; Mendonça et al., 2016). As observed by the mini-SAS system, no difference was found regarding external characteristics, therefore, we do not recommend the use of such parameters when doing qualitative evaluation of $M$. polymorphum seed lots.

The seed groups obtained by the X-ray test (filled, malformed and unfilled) directly influenced germination. As shown in Table 3, only filled seeds germinated and emitted normal seedlings. On the contrary, unfilled, and malformed seeds had no germination.

It was found that not all filled seeds germinated and/or formed normal seedlings. Abnormal seedlings were defined as having no potential to growth to a normal plant.

\subsection{Seed separation in the blower}

The heavy fraction had the largest number of filled seeds since they have higher density than unfilled and malformed seeds. The results regarding the percentage of the heavy fraction weight and filled seeds for opening settings are in Tables 4 and 5.

Airflow increases with the number of the seed blower openings, therefore the heavy fraction weight (compared to its original weight) decreased with opening settings, reaching the lowest at opening 6 , when it was $5.18 \%$ of the original sample weight. Opening 1 had the highest percentage of heavy fraction weight of seeds, with an average value of $52.51 \%$ of the original sample (Table 4 ).

When evaluated by the X-ray test, the opening settings 5 and 6 resulted in the highest percentage of filled seeds, whereas the opening settings 1 and 2 led to the lowest percentage of filled seeds (Table 5).

Socolowski and Cicero (2008) claim that seed mass is an indicator of physiological quality and that radiograph images are crucial to assess the physical quality of seeds. This has been confirmed by Amaral et al. (2011) for seeds of Tabebuia heptaphylla and by Feitosa et al. (2009) for seeds of Eremanthus erythropappus. In this study, the percentage of filled seeds was linked to the increase of air flow in the opening settings of the seed blower. 
Table 2. Mean results of dominant color, area, maximum diameter, minimum diameter, perimeter, and predominant color of the three groups of seeds of M. polymorphum, as observed by the mini-SAS system.

\begin{tabular}{ccccccc}
\hline Categorization & $\begin{array}{c}\text { Predominant } \\
\text { color }\end{array}$ & $\begin{array}{c}\text { Area } \\
\left(\mathbf{m m}^{\mathbf{2}}\right)\end{array}$ & $\begin{array}{c}\text { Maximum } \\
\text { diameter }(\mathbf{m m})\end{array}$ & $\begin{array}{c}\text { Minimum } \\
\text { diameter } \mathbf{( m m})\end{array}$ & $\begin{array}{c}\text { Ratio Dmax/ } \\
\text { Dmin }\end{array}$ & $\begin{array}{c}\text { Perimeter } \\
(\mathbf{m m})\end{array}$ \\
\hline Unfilled & Dark & 1.74 & 3.116 & 0.652 & 4.779 & 7.437 \\
Malformed & Dark & 1.85 & 3.031 & 0.712 & 4.254 & 7.483 \\
Filled & Dark & 1.87 & 3.057 & 0.718 & 4.253 & 7.553 \\
\hline
\end{tabular}
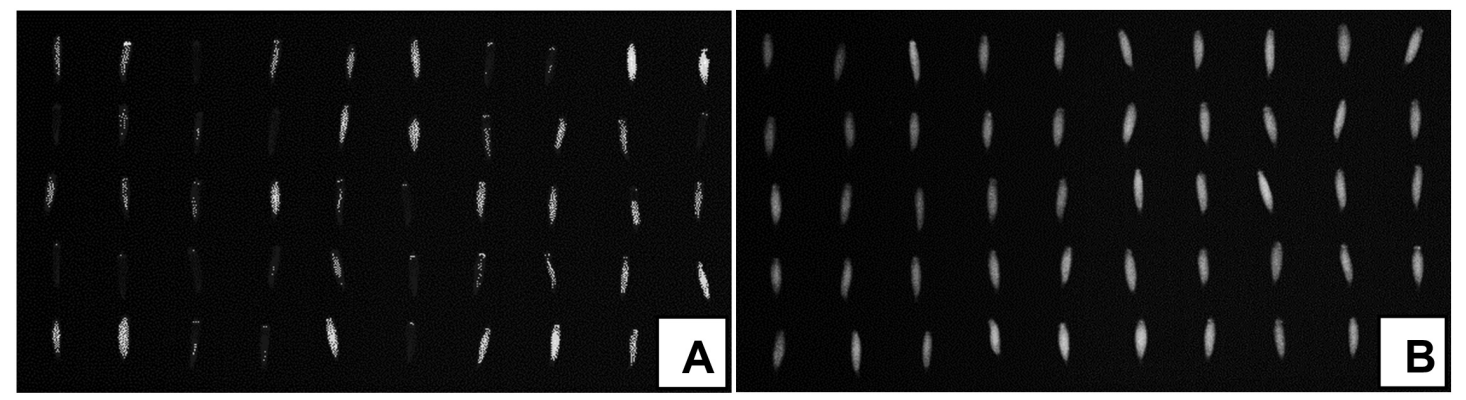

Figure 2. Radiograph images obtained from two samples of seeds separated by the blower: (A) heavy fraction from opening setting 1 ; and (B) heavy fraction from opening setting 6.

This indicates an increase in the quality of the final sample of the heavy fraction.

Figure 2 shows the difference of unfilled, malformed and filled seeds for the opening settings 1 and 6 . This demonstrates that the separation by the seed blower improved the quality of the seed lot.

Germination tests at $30{ }^{\circ} \mathrm{C}$ and constant lighting were carried out to verify the quality of the seeds that were blown through the six opening settings. Root emission and normal seedling formation mean values ranged from 24 to $80 \%$ and 24 to $74 \%$, respectively. From opening setting 5, no significant increase is observed in the percentage of radicle protrusion and normal seedling. As expected, seeds from opening setting 1 had the lowest mean values for radicle protrusion and normal seedling and highest values for dead seeds (Table 6). Similarly, the percentage of dead seeds decreases with the increase in airflow. This highlights the efficiency of General seed blower to separate filled seeds from unfilled and malformed seeds. Unfilled seeds were considered as dead seeds at the end of the test.

Regarding the percentage of hard seeds, all treatments were statistically equal. It is known that variation in temperature, light, oxygen, and humidity are the most common conditions that affect germination for hard seeds (Zucareli et al., 2015; Lone et al., 2016).

Based on the results shown in Tables 4, 5 and 6, the opening settings 4, 5 and 6 were superior to qualitatively separate seeds of $M$. polymorphum. We recommend opening setting 5 , as the fraction performed better in the germination test compared to opening setting 4 , and it showed greater heavy fraction weight than opening setting 6 .

Subsequently, moisture and weight of one thousand seeds were again determined for the seed lot from opening setting 5. The moisture content and weight of one thousand seeds were $7.35 \%$ and $0.8642 \mathrm{~g}$, respectively.
Table 3. Germination test results for filled, malformed and unfilled seeds of de M. polymorphum.

\begin{tabular}{cccc}
\hline \multirow{2}{*}{ Criteria } & \multicolumn{3}{c}{ Seeds conditions (\%) } \\
\cline { 2 - 4 } & Filled & Malformed & Unfilled \\
\hline Radicle protrusion & 69.23 & 0 & 0 \\
Normal seedling & 46.15 & 0 & 0 \\
\hline
\end{tabular}

Table 4. Percentage of the heavy fraction weight for seeds of $M$. polymorphum, after passing through seed blower with opening settings $1,2,3,4,5$ and 6 .

\begin{tabular}{cc}
\hline Opening & Heavy fraction (\%) \\
\hline 1 & $52.51 \mathrm{a}$ \\
2 & $42.22 \mathrm{~b}$ \\
3 & $34.20 \mathrm{c}$ \\
4 & $26.36 \mathrm{~d}$ \\
5 & $15.56 \mathrm{e}$ \\
6 & $5.18 \mathrm{f}$ \\
\hline
\end{tabular}

Means followed by the same small letter in a row and capital letter in a column are similar by the Tukey test at the $5 \%$ probability level.

Table 5. Mean percentages of embryonic seeds of M. polymorphum in the heavy fraction for each opening setting, as observed by the X-ray test.

\begin{tabular}{cc}
\hline Opening & Filled seeds (\%) \\
\hline 1 & $46 \mathrm{~d}$ \\
2 & $50 \mathrm{~d}$ \\
3 & $76 \mathrm{c}$ \\
4 & $90 \mathrm{~b}$ \\
5 & $100 \mathrm{a}$ \\
6 & $100 \mathrm{a}$ \\
\hline
\end{tabular}

Means followed by the same letter in a column do not differ by the Tukey test at the $5 \%$ probability level. 
Table 6. Germination test results of the heavy fractions for six opening settings tested by the seed blower for M. polymorphum seeds.

\begin{tabular}{ccccc}
\hline \multirow{2}{*}{ Opening } & $\begin{array}{c}\text { Radicle } \\
\text { protrusion }\end{array}$ & $\begin{array}{c}\text { Normal } \\
\text { seedling }\end{array}$ & $\begin{array}{c}\text { Dead } \\
\text { seeds }\end{array}$ & $\begin{array}{c}\text { Hard } \\
\text { seeds }\end{array}$ \\
\cline { 2 - 5 } \% \\
\hline 1 & $24 \mathrm{~d}$ & $24 \mathrm{~d}$ & $70 \mathrm{a}$ & $6 \mathrm{a}$ \\
2 & $38 \mathrm{c}$ & $36 \mathrm{c}$ & $55 \mathrm{~b}$ & $7 \mathrm{a}$ \\
3 & $64 \mathrm{~b}$ & $58 \mathrm{~b}$ & $26 \mathrm{c}$ & $10 \mathrm{a}$ \\
4 & $66 \mathrm{~b}$ & $60 \mathrm{~b}$ & $26 \mathrm{c}$ & $8 \mathrm{a}$ \\
5 & $80 \mathrm{a}$ & $74 \mathrm{a}$ & $13 \mathrm{~d}$ & $7 \mathrm{a}$ \\
6 & $78 \mathrm{a}$ & $74 \mathrm{a}$ & $14 \mathrm{~d}$ & $8 \mathrm{a}$ \\
\hline
\end{tabular}

Means followed by the same letter in a column do not differ by the Tukey test at the $5 \%$ probability level.

\section{Conclusions}

The use of a General seed blower plus an X-ray system is efficient for assessing physical quality in seeds of M. polymorphum.

To improve the seed lot of M. polymorphum, it is recommended to use opening setting 5 in the General seed blower, which is the one that obtains the largest number of filled seeds.

The external parameters evaluated by the mini-SAS system were not able to qualitatively evaluate the filled, unfilled, and malformed seeds, and its use is not recommended for the characterization of M. polymorphum seed lots.

\section{References}

AMARAL, J.B., MARTINS, L., FORTI, V.A., CÍCERO, S.M. and MARCOS FILHO, J., 2011. Teste de raios x para avaliação do potencial fisiológico de sementes de ipê-roxo. Revista Brasileira de Sementes, vol. 33, no. 4, pp. 601-607. http://dx.doi.org/10.1590/ S0101-31222011000400001.

BRASIL, 1998 [viewed 5 February 2017]. Lei ${ }^{\circ} 9.605$, de 12 de fevereiro de 1998. Dispõe sobre as sanções penais e administrativas derivadas de condutas e atividades lesivas ao meio ambiente, $e$ dá outras providências. Diário Oficial da República Federativa do Brasil [online], Brasília, 13 fev. Available from: http://www. planalto.gov.br/ccivil_03/leis/19605.htm

BRASIL. Ministério da Agricultura, Pecuária e Abastecimento. Secretaria de Defesa Agropecuária, 2009 [viewed 5 February 2017]. Regras para análise de sementes [online]. Brasília: MAPA/ACS, 395 p. Available from: http://www.agricultura.gov.br/arq_editor/ file/2946_regras_analise_sementes.pdf

BRASIL, 2012 [viewed 5 February 2017]. Lei no 12.651, de 25 de maio de 2012. Dispõe sobre a proteção da vegetação nativa; altera as Leis nos 6.938, de 31 de agosto de 1981, 9.393, de 19 de dezembro de 1996, e 11.428, de 22 de dezembro de 2006; revoga as Leis nos 4.771, de 15 de setembro de 1965, e 7.754, de 14 de abril de 1989, e a Medida Provisória no 2.166-67, de 24 de agosto de 2001; e dá outras providências. Diário Oficial da República Federativa do Brasil [online], Brasília, 28 maio. Available from: http://www.planalto.gov.br/ccivil_03/_Ato20112014/2012/Lei/L12651.htm
CARVALHO, L.R., CARVALHO, M.L.M. and DAVIDE, A.C.A.C., 2009. Utilização do teste de raios x na avaliação da qualidade de sementes de espécies florestais de Lauraceae. Revista Brasileira de Sementes, vol. 31, no. 4, pp. 57-66. http://dx.doi.org/10.1590/ S0101-31222009000400007.

CARVALHO, P.E.R., 2003. Espécies arbóreas brasileiras. Colombo: Embrapa Florestas, 1040 p.

CASTELLANI, E.D., AGUIAR, I.B. and PAULA, R.C., 2007. Colheita de frutos, extração e beneficiamento de sementes de solanáceas arbóreas. Informativo ABRATES, vol. 17, no. 1-3, pp. 69-75.

FEITOSA, S.S., DAVIDE, A.C., TONETTI, O.A.O., FABRICANTE, J.R. and LUI, J.J., 2009. Estudos de viabilidade de sementes de candeia (Eremanthus erythropappus (dc.) macleish) por meio de testes de germinação e raios X. Floresta, vol. 39, no. 2, pp. 393-399. http://dx.doi.org/10.5380/rf.v39i2.14565.

FERREIRA, D.F., 2011. Sisvar: a computer statistical analysis system. Ciência e Agrotecnologia, vol. 35, no. 6, pp. 1039-1042. http://dx.doi.org/10.1590/S1413-70542011000600001.

LONE, A.B., COLOMBO, R.C., ANDRADE, B.L.G., TAKAHASHI, L.S.A. and FARIA, R.T., 2016. Physical characterization of Rhipsalis (Cactaceae) fruits and seeds germination in different temperatures and light regimes. Brazilian Journal of Biology $=$ Revista Brasileira de Biologia, vol. 76, no. 2, pp. 367-373. http:// dx.doi.org/10.1590/1519-6984.15914. PMid:26934150.

LOPES, J.C., DIAS, P.C. and PEREIRA, M.D., 2005. Maturação fisiológica de sementes de quaresmeira. Pesquisa Agropecuária Brasileira, vol. 40, no. 8, pp. 811-816. http://dx.doi.org/10.1590/ S0100-204X2005000800012.

LORENZI, H., 2014. Árvores brasileiras: manual de identificação e cultivo de plantas arbóreas nativas do Brasil. 6. ed. Nova Odessa: Plantarum, 384 p. vol. 1.

MACHADO, D.F.M., TAVARES, A.P., LOPES, S.J. and SILVA, A.C.F., 2015. Trichoderma spp. na emergência e crescimento de mudas de cambará (Gochnatia polymorpha (Less.) Cabrera). Revista Árvore, vol. 39, no. 1, pp. 167-176. http://dx.doi. org/10.1590/0100-67622015000100016.

MARZINEK, J., DE-PAULA, O.C. and OLIVEIRA, D.M.T., 2008. Cypsela or achene? Refining terminology by considering anatomical and historical factors. Brazilian Journal of Botany, vol. 31, no. 3, pp. 549-553. http://dx.doi.org/10.1590/S010084042008000300018 .

MASETTO, T.E., FARIA, J.M.R. and QUEIROZ, S.E., 2008. Avaliação da qualidade de sementes de cedro (Cedrella fissilis Meliaceae) pelo teste de raios X. Ciência e Agrotecnologia, vol. 32, no. 6, pp. 1-7. http://dx.doi.org/10.1590/S1413-70542008000600004.

MENDONÇA, A.V.R., FREITAS, T.A.S., SOUZA, L.S., FONSECA, M.D.S. and SOUZA, J.S., 2016. Morphology of fruit and seed and germination on Poincianella pyramidalis (Tul.) LP Queiroz, comb. Nov. Ciência Florestal, vol. 26, no. 2, pp. 375-387. http:// dx.doi.org/10.5902/1980509822738.

NERY, F.C., PRUDENTE, D.O., ALVARENGA, A.A., PAIVA, R. and NERY, M.C., 2017. Armazenamento de sementes de Calophyllum brasiliense Cambess. Brazilian Journal of Biology $=$ Revista Brasileira de Biologia, vol. 77, no. 3, pp. 431-436. http://dx.doi.org/10.1590/1519-6984.08115.

NOGUEIRA, A.C., 2007. Extração e beneficiamento de sementes florestais nativas. Colombo: Embrapa, 7 p. Circular Técnica, no. 131. 
PEREIRA, G.P. and CARVALHO, R.I.N., 2008. Valor cultural de semente de agapantos após classificação em soprador de sementes. Scientia Agraria, vol. 9, no. 4, pp. 439-443. http:// dx.doi.org/10.5380/rsa.v9i4.11704.

PINTO, C.A.G., CARVALHO, M.L.M.D., ANDRADE, D.B.D., LEITE, E.R. and CHALFOUN, I., 2015. Image analysis in the evaluation of the physiological potential of maize seeds. Revista Ciência Agronômica, vol. 46, no. 2, pp. 319-328. http://dx.doi. org/10.5935/1806-6690.20150011.

PINTO, G.F.D.S. and KOLB, R.M., 2015. Seasonality affects phytotoxic potential of five native species of Neotropical savanna. Botany, vol. 94, no. 2, pp. 81-89. http://dx.doi.org/10.1139/ cjb-2015-0124.

REGO, S.S., NOGUEIRA, A.C., KUNIYOSHI, Y.S. and SANTOS, A.F., 2009. Germinação de sementes de Blepharocalyx salicifolius (H.B.K.) Berg. em diferentes substratos e condições de temperaturas, luz e umidade. Revista Brasileira de Sementes, vol. 31, no. 2, pp. 212-220. http://dx.doi.org/10.1590/S0101-31222009000200025.

ROSSATTO, D.R. and KOLB, R.M., 2010. Gochnatia polymorpha (Less.) Cabrera (Asteraceae) changes in leaf structure due to differences in light and edaphic conditions. Acta Botanica Brasílica, vol. 24, no. 3, pp. 605-612. http://dx.doi.org/10.1590/ S0102-33062010000300002.

SANTOS, J.P., DAVIDE, A.C., TEIXEIRA, L.A.F., MELO, A.J.S. and MELO, L.A., 2011. Enraizamento de estacas lenhosas de espécies florestais. Cerne, vol. 17, no. 3, pp. 293-301. http:// dx.doi.org/10.1590/S0104-77602011000300002.

SILVA, L.A., SALES, J.D.F., GUIMARÃES, R.M., OLIVEIRA, J.A. and VASCONCELOS FILHO, S.C., 2015. Morphological aspects of fruits, seeds and seedlings of Rhamnidium elaeocarpum Reissek. Semina: Ciências Agrárias, vol. 36, no. 3, pp. 1179-1190. http://dx.doi.org/10.5433/1679-0359.2015v36n3p1179.

SIMAK, M., BERGSTEN, U. and HENRIKSSON, G., 1989. Evaluation of ungerminated seeds at the end of germination test by radiography. Seed Science and Technology, vol. 17, pp. 361-369.

SOCOLOWSKI, F. and CÍCERO, S.M., 2008. Caracterização morfológica de embriões por imagens de raios X e relação com a massa e a qualidade fisiológica de sementes de Tecoma stans L. Juss ex Kunth (Bignoniaceae). Revista Brasileira de Sementes, vol. 30, no. 2, pp. 200-208. http://dx.doi.org/10.1590/S010131222008000200025 .

SOUZA, P.H., PAIVA, H.N., NEVES, J.C.L., GOMES, J.M. and MARQUES, L.S., 2010. Crescimento e qualidade de mudas de Senna macranthera (collad.) Irwin et Barn. em resposta à calagem. Revista Árvore, vol. 34, no. 2, pp. 233-240. http://dx.doi. org/10.1590/S0100-67622010000200005.

ZUCARELI, V., HENRIQUE, L.A.V. and ONO, E.O., 2015. Influence of light and temperature on the germination of Passiflora incarnata L. seeds. Journal of Seed Science, vol. 37, no. 2, pp. 162-167. http://dx.doi.org/10.1590/2317-1545v37n2147082. 